University of Nebraska - Lincoln

DigitalCommons@University of Nebraska - Lincoln

1990

\title{
Phytoplankton Dynamics in Three Rocky Mountain Lakes, Colorado, U.S.A.
}

Diane M. Mcknight

U.S. Geological Surve

Richard L. Smith

U.S. Geological Surve

J. Platt Bradbury

U.S. Geological Surve

Jill S. Baron

National Park Service, Water Resources Laboratory

Sarah Spaulding

National Park Service, Water Resources Laboratory

Follow this and additional works at: https://digitalcommons.unl.edu/usgsstaffpub

Part of the Earth Sciences Commons

Mcknight, Diane M.; Smith, Richard L.; Bradbury, J. Platt; Baron, Jill S.; and Spaulding, Sarah, "Phytoplankton Dynamics in Three Rocky Mountain Lakes, Colorado, U.S.A." (1990). USGS Staff -Published Research. 258.

https://digitalcommons.unl.edu/usgsstaffpub/258

This Article is brought to you for free and open access by the US Geological Survey at DigitalCommons@University of Nebraska - Lincoln. It has been accepted for inclusion in USGS Staff -- Published Research by an authorized administrator of DigitalCommons@University of Nebraska - Lincoln. 


\title{
PHYTOPLANKTON DYNAMICS IN THREE ROCKY MOUNTAIN LAKES, COLORADO, U.S.A.
}

\author{
Diane M. McKnight, Richard L. Smith, and J. Platt Bradbury \\ U.S. Geological Survey, P.O. Box 25046, Mail Stop 408 \\ Denver, Colorado 80225, U.S.A. \\ Jill S. Baron and SaRah Spaulding \\ National Park Service, Water Resources Laboratory \\ 105 Grasslands Laboratory, Colorado State University \\ Fort Collins, Colorado 80523, U.S.A.
}

\begin{abstract}
In 1984 and 1985 seasonal changes in phytoplankton were studied in a system of three lakes in Loch Vale, Rocky Mountain National Park, Colorado. Three periods were evident: (1) A spring bloom, during snowmelt, of the planktonic diatom Asterionella formosa, (2) a midsummer period of minimal algal abundance, and (3) a fall bloom of the blue-green alga Oscillatoria limnetica. Seasonal phytoplankton dynamics in these lakes are controlled partially by the rapid flushing rate during snowmelt and the transport of phytoplankton from the highest lake to the lower lakes by the stream, Icy Brook. During snowmelt, the $A$. formosa population in the most downstream lake has a net rate of increase of $0.34 \mathrm{~d}^{-1}$, which is calculated from the flushing rate and from the $A$. formosa abundance in the inflow from the upstream lake and in the downstream lake. Measurement of photosynthetic rates at different depths during the three periods confirmed the rapid growth of $A$. formosa during the spring. The decline in $A$. formosa after snowmelt may be related to grazing by developing zooplankton populations. The possible importance of the seasonal variations in nitrate concentrations were evaluated in situ enrichment experiments. For $A$. formosa and $O$. limnetica populations, growth stimulation resulted from 8- or 16-micromolar amendments of calcium nitrate and sulfuric acid, but the reason for this stimulation could not be determined from these experiments.
\end{abstract}

\section{INTRODUCTION}

In European alpine and subalpine lakes the phytoplankton is commonly dominated by flagellates (chrysophytes, dinoflagellates, and cryptophytes) (Goldman and Horne, 1983). After breakup of the ice cover in the spring, the phytoplankton maximum occurs at depth (as deep as 15 to $20 \mathrm{~m}$ ) (Rott, 1988). This sequence has been interpreted as an avoidance of intense sunlight by the flagellates. Phytoplankton dynamics in alpine and subalpine lakes in the southern Rocky Mountains have not been studied as extensively; however, some significant differences are indicated. In Rocky Mountain lakes, diatoms are often abundant in the phytoplankton (Brinley, 1950; Olive, 1953; Keefer and Pennak, 1977; Shero, pers. comm., 1987) and in lacustrine sediments (Baron et al., 1986). Furthermore, Koob (1966) reported blooms of the planktonic diatom Asterionella formosa occurring during snowmelt each year of a 3-yr study of two lakes in the Rawah Wilderness Area of Colorado. The purpose 
of our study was to develop a better understanding of seasonal phytoplankton dynamics in a lake system in the Front Range of the Colorado Rocky Mountains. Phytoplankton dynamics were observed in Loch Vale Watershed over $2 \mathrm{yr}$, and possible limitations to growth were explored with short-term enrichment and acidification experiments. The phytoplankton ecology of Rocky Mountain lakes is important in (1) evaluating potential impacts of changing atmospheric deposition from urban or industrial development and (2) using lacustrine sediments as records of past climatic conditions (Baron et al., 1986).

In temperate lakes, seasonal changes in phytoplankton abundance and species distribution are related to ecological interactions and seasonal changes in physical and chemical conditions, such as light intensity, hydrologic mixing, nutrient availability, and temperature (Wetzel, 1983; Reynolds, 1984). In this context, ice breakup and snowmelt are extreme, coincident events that could be dominant controls on phytoplankton dynamics in Rocky Mountain lakes. In some lakes, ice breakup causes a sudden shift from light-limited conditions under snow and ice cover to high light intensities with only minimal attenuation by particulates and dissolved materials. Melting of the accumulated winter snowpack causes both rapid flushing rates and changes in the concentrations of dissolved constituents. During snowmelt, Keefer and Pennak (1977) reported a flushing rate of $58 \%$ of the lake volume per day for Long Lake in Colorado. For some constituents, such as major cations, inflowing water during snowmelt is more dilute than the lakewater, which is freeze concentrated by ice formation. For constituents which are deposited with the snowpack or flushed from upper soil horizons, concentrations may increase during snowmelt (Lewis and Grant, 1979). Two ecologically significant constituents which increase during snowmelt in lakes in Rocky Mountain National Park are dissolved organic carbon and nitrate, a major nutrient for phytoplankton (McKnight et al., 1988).

Because of the possible importance of the increased nitrate during snowmelt, we conducted enrichment experiments to assess phytoplankton sensitivity to increased nitrate and acidity. Individual species, especially of diatoms, are reported to have narrow $\mathrm{pH}$ tolerance ranges (Charles, 1986), and indices of lake acidity status have been developed from the $\mathrm{pH}$ preferences of diatom assemblages (Renberg and Hellberg, 1982). Since little work has been done on the responses of Rocky Mountain phytoplankton to increasing acidity (Baron et al., 1986), and since there is concern over the potential for lake acidification, we ran in situ acidification experiments on both spring and late summer phytoplankton. While much of the acidic deposition in northeastern North America and Scandinavia has been related to sulfuric acid deposition, concentrations of $\mathrm{SO}_{4}$ and $\mathrm{NO}_{3}$ are roughly equal in volume-weighted mean annual precipitation at Loch Vale (Baron and Bricker, 1987).

\section{STUDY AREA}

This study was conducted during 1984 and 1985 primarily at The Loch, the most downstream of three lakes in the Loch Vale watershed in Rocky Mountain National Park, Colorado, and to a lesser degree in Glass Lake and Sky Pond (Figure 1A). Each lake occupies a glacially formed cirque. Morphometric data for all three lakes are summarized in Table 1. All lakes are dilute and circumneutral ( $\mathrm{pH} 6.0$ to 6.8), as shown by the lake-waterchemistry data in Table 2 . The lakes are connected by an intermittent stream, Icy Brook. Two other streams, Andrews Creek and Little Loch Creek, flow into Icy Brook just upstream from its inlet to The Loch. The lakes do not become thermally stratified. The Loch usually was sampled at a site over a depression near the southeastern shore of the lake (Figure 1B). The Loch is surrounded by a spruce and fir forest and, at an elevation of 3048 $\mathrm{m}$ above sea level, is classified as a subalpine lake (Pennak, 1963).

\section{MATERIALS AND METHODS}

Samples were collected, using a VanDorn ${ }^{1}$ sampler, at three depths from The Loch, Glass Lake, and Sky Pond during 1984 and 1985 . The lakes were sampled between May and October on 10 occasions in 1984 and on 13 occasions in 1985. Samples for phytoplankton enumeration $(1 \mathrm{~L})$ were preserved promptly with formaldehyde $(5 \%$ in water). Zooplankton were collected using a SchindlerPatalas zooplankton sampler (30.5 L sample volume). Plankton species were identified and counted using settling columns and a Leitz inverted microscope following

\footnotetext{
${ }^{1}$ The use of trade or firm names in this report is for identification purposes only and does not constitute endorsement by the U.S. Geological Survey.
}

the method of Lund et al. (1958) for phytoplankton. Duplicate phytoplankton samples were enumerated on 10 July and 8 August 1985, and the range in total cell count was $\pm 5 \%$ and $\pm 30 \%$ on the two days, and the species distribution was very similar for the duplicates (McKnight et al., 1988). Samples for chlorophyll $a$ determinations were filtered through Gelman GFC glass-fiber filters, extracted in acetone, corrected for phaeopigments using the method described by Strickland and Parsons (1972), and analyzed using a Turner Designs model-10 series fluorometer.

Samples for chemical analysis were filtered through $0.4-\mu \mathrm{m}$ Nuclepore filters into $250-\mathrm{ml}$, acid-washed, deionized-water rinsed, plastic bottles. Analyses for nutrients and other constituents were performed by the 
A. Location of study lakes and instrumentation

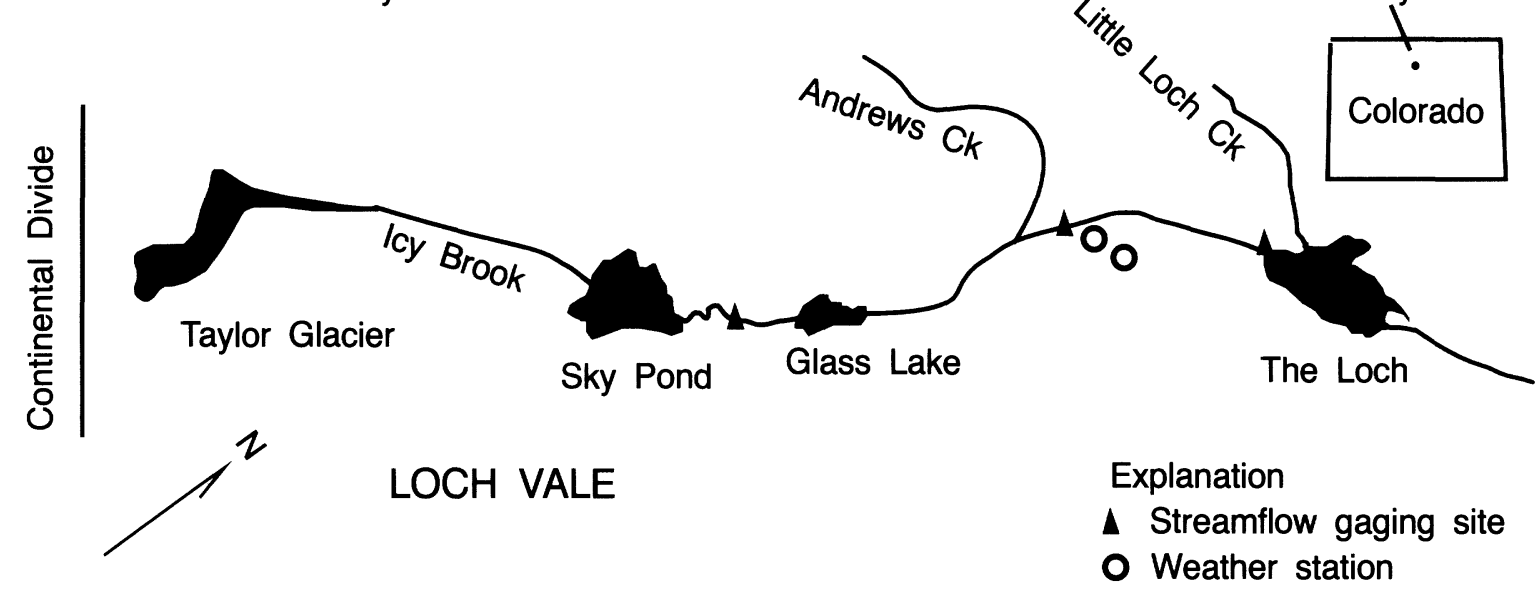

B. Bathymetry of the Loch and location of sampling sites

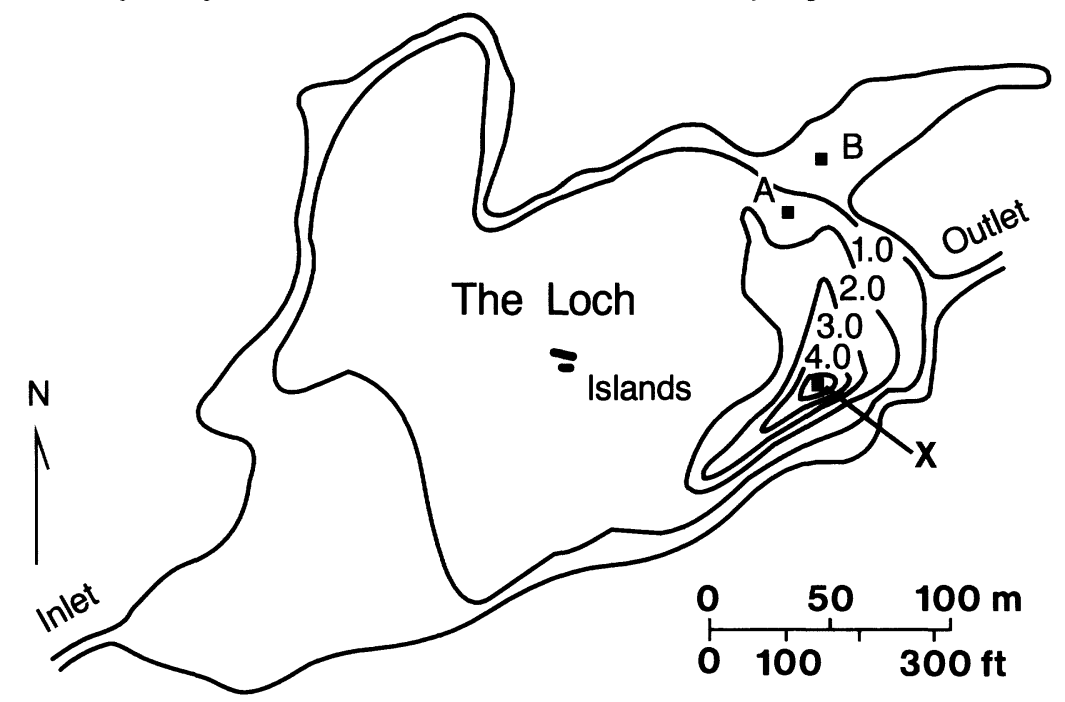

A. Sampling site

FIGURE 1. Plan view of Loch Vale Watershed (A) and bathymetric contours (m) of The Loch (B) showing main sampling site (X) and sites used on 17 September 1985 (A and B) because of strong winds.

U.S. Geological Survey's Water Quality Laboratory, Denver, Colorado, using methods described by Skougstad et al. (1979). Alkalinity was measured by using a Gran's titration and reported in milligram per liter as $\mathrm{CaCO}_{3}$. The intensity of photosynthetically active radiation (PAR: from 400 to $700 \mathrm{~nm}$ ) and water temperature were measured at 0.5 - or $1-\mathrm{m}$ depth intervals in each lake, using a LI-COR lightmeter.

On three dates at The Loch (the most accessible of the lakes in Loch Vale), rates of photosynthesis at different depths were measured by in situ incubation using the general procedure described by Vollenweider (1969). On 3 June and 8 August 1985, three 300-ml samples in biochemical oxygen demand (BOD) bottles (two light bottles and one dark bottle) were collected at site X at 1-m
TABLE 1

Morphometric characteristics of the study lakes

\begin{tabular}{lccccc}
\hline Lake & $\begin{array}{c}\text { Elevation } \\
(\mathrm{m})\end{array}$ & $\begin{array}{c}\text { Surface } \\
\text { area } \\
(\mathrm{ha})\end{array}$ & $\begin{array}{c}\text { Lake } \\
\text { volume } \\
\left(\mathrm{m}^{3}\right)\end{array}$ & $\begin{array}{c}\text { Average Maximum } \\
\text { depth }\end{array}$ & $\begin{array}{c}\text { depth } \\
\text { (m) }\end{array}$ \\
\hline The Loch & 3048 & 4.98 & 61,099 & 1.5 & 4.7 \\
Sky Pond & 3322 & 3.03 & 121,684 & 4.5 & 7.3 \\
Glass Lake & 3292 & 1.01 & 25,690 & 2.8 & 4.7
\end{tabular}

depth intervals $(0,1,2,3$, and $4 \mathrm{~m})$ and were spiked using $0.5 \mathrm{ml}$ of a ${ }^{14} \mathrm{C}-\mathrm{HCO}_{3}$ (New England Nuclear) tracer solution. The samples were placed on an anchored line suspended from a buoy at the depth of collection and in- 
cubated for the same period (several hours) during midday. On 17 September 1985, samples were collected and incubated at the surface and at a depth of $1 \mathrm{~m}$ at a shallow site (A) closer to shore because strong winds prevented collecting samples from the usual sampling site. Black plastic shields were used to prevent exposure of the samples to surface light during handling. On all three dates, the maximum light intensity during the incubation was 1900 to $2000 \mu \mathrm{E} \cdot \mathrm{m}^{-2} \cdot \mathrm{s}^{-1}$ at the lake surface. The minimum light intensity at the lake surface was 750 $\mu \mathrm{E} \cdot \mathrm{m}^{-2} \cdot \mathrm{s}^{-1}$ on $3 \mathrm{June}, 1500 \mu \mathrm{E} \cdot \mathrm{m}^{-2} \cdot \mathrm{s}^{-1}$ on 8 August and $400 \mu \mathrm{E} \cdot \mathrm{m}^{-2} \cdot \mathrm{s}^{-1}$ on 17 September. After incubation of the samples, one $200-\mathrm{ml}$, or two $100-\mathrm{ml}$, aliqouts from each BOD bottle were filtered through a GFC glass-fiber filter. The filters were stored in glass scintillation vials in $5 \mathrm{ml}$ of $5 \%$ acetic acid in methanol to purge inorganic ${ }^{14} \mathrm{C}$ and dried on arrival at the laboratory; radioactivity on the filters was counted (after addition of $10 \mathrm{ml}$ of Aquasol) using a model LS7800 Beckman scintillation counter. On 8 August, other methods of handling the samples after incubation were tested; we determined that (1) GFC filters yielded the greater recovery of labelled particulate material than GN-6 filters, (2) recovery was the same for purging inorganic ${ }^{14} \mathrm{C}$ by fuming with $\mathrm{HCl}$ or by addition and evaporation of $5 \%$ acetic acid in methanol, and (3) about $20 \%$ of the total fixed carbon was released as dissolved organic carbon (McKnight et al., 1988).

On 3 June and 17 September 1985, photosynthetic rate was measured for duplicate samples amended with concentrations of $\mathrm{Ca}\left(\mathrm{NO}_{3}\right)_{2}, \mathrm{HNO}_{3}$, and $\mathrm{H}_{2} \mathrm{SO}_{4}$ ranging from 3.2 to $808 \mu \mathrm{M}$ (as final concentrations in the incubated samples). The amendment solutions were analyzed for trace metals ( $\mathrm{Al}, \mathrm{Cd}, \mathrm{Co}, \mathrm{Cu}, \mathrm{Fe}, \mathrm{Mn}, \mathrm{Ni}, \mathrm{Pb}$, and
TABLE 2

Representative data for dissolved chemical constituents in The Loch during snowmelt (3 June) and lowflow (20 August 1985)

\begin{tabular}{lcc}
\hline & \multicolumn{2}{c}{ Hydrologic Regime } \\
\cline { 2 - 3 } & Snowmelt & Lowflow \\
\hline $\mathrm{pH}$ & - & 6.5 \\
Alkalinity $\left(\mu \mathrm{eq} \mathrm{L}^{-1}\right)$ & 38 & 40 \\
Chlorophyll $a\left(\mu \mathrm{g} \mathrm{L}^{-1}\right.$ & 1.2 & 2.3 \\
Constituent $(\mu \mathrm{M})$ & & \\
$\mathrm{NO}_{3}$ & 82 & 38 \\
$\mathrm{NO}_{2}$ & 1.4 & 0.7 \\
$\mathrm{NH}_{4}$ & 1.0 & 1.5 \\
$\mathrm{PO}_{4}$ & 0.4 & 0.1 \\
$\mathrm{SiO}_{2}$ & 33 & 21 \\
$\mathrm{Ca}$ & 37 & 27 \\
$\mathrm{SO}_{4}$ & 18 & 11 \\
$\mathrm{Fe}$ & 0.6 & 0.3 \\
$\mathrm{Mn}$ & 0.02 & 0.03 \\
\hline
\end{tabular}

${ }^{a}$ Complete data set for sampling dates in 1984 and 1985 are presented, with results of replicate analyses, by McKnight et al. (1986, 1988).

$\mathrm{Zn)}$ by inductively coupled plasma spectrometry. The trace-metal concentrations in the incubated samples were similar to or less than the detection limit, corresponding to concentrations of less than or equal to 0.1 to $0.05 \mu \mathrm{M}$. On 3 June, the amended samples were collected and incubated at a depth of $2 \mathrm{~m}$ and on 17 September they were collected and incubated at a depth of $1 \mathrm{~m}$. Further experimental details are described by McKnight et al. (1988).

\section{RESULTS}

Phytoplankton Abundance in LaKes of Loch Vale The phytoplankton abundance in The Loch and in Sky Pond during 1984 and 1985 is presented in Figure 2, and the discharge at the outlet of Icy Brook from The Loch is presented in Figure 3. The complete data for phytoplankton identification and enumeration are presented by McKnight et al. $(1986,1988)$. Throughout the openwater period, the phytoplankton-species composition in the three lakes in Loch Vale was usually similar (McKnight et al., 1986, 1988); the main difference among the lakes was the greater abundance in Sky Pond than in The Loch (Figure 2). This difference in algal abundance also accounted for the 2- to 10 -fold greater chlorophyll $a$ concentrations in Sky Pond (McKnight et al., 1988). A snowmelt bloom of Asterionella formosa and a fall bloom of Oscillatoria limnetica, with an intervening period of greater chlorophyte abundance, were dominant and recurring events in 1984 and 1985 (Figure 2).

As stated previously, diatoms are commonly abundant in Rocky Mountain lakes, and Asterionella formosa is a common species (Brinley, 1950; Olive, 1953; Koob,
1966; Keefer and Pennak, 1977; Baron et al., 1986; Shero, pers. comm., 1987). Asterionella formosa was the dominant species in two lakes in the Rawah Wilderness Area of Colorado, forming blooms during snowmelt for three successive years and in the fall of one year (Koob, 1966). Asterionella formosa from The Loch is shown in Figure 4. Asterionella formosa is susceptible to parasitism by the chytrid Rhizophydium planktonicum (Canter and Jaworski, 1978), and such parasitism was observed in studies by Koob (1966) and in samples collected from The Loch in early winter (S. Spaulding, unpublished data).

The net rate of increase for $A$. formosa population in The Loch on given days was calculated based on the abundance of $A$. formosa in the Icy Brook inflow, the average abundance of $A$. formosa in The Loch, and the flushing rate for The Loch computed for that day from discharge measurements. These net within-lake growth rates for 1985 are tabulated in Table 3; the average rate from 3 June to 23 July was $0.34 \mathrm{~d}^{-1}$. These rates were slower than the actual rate of cell division for $A$. formosa in The Loch because: (1) The effects of any settling, graz- 
ing, or other in-lake losses were not accounted for; and (2) all the $A$. formosa cells in the inflow were assumed to be viable and "in good condition" despite their previous passage down Icy Brook, which is turbulent and has more suspended material during snowmelt. These computed rates are slower than maximum growth rates for $A$. formosa in continuous culture experiments, $1.34 \pm 0.16 \mathrm{~d}^{-1}$ (Sommer, 1983) and $0.76 \mathrm{~d}^{-1}$ (Tilman and Kilham, 1976). This comparison shows that $A$. formosa population in The Loch was growing at a rate within its physiological range.

Although late summer blue-green algal blooms are common in temperate lakes (Wetzel, 1983), there is little documentation of such blue-green algal blooms in alpine lakes in Colorado (Pennak, 1949). In September 1988,
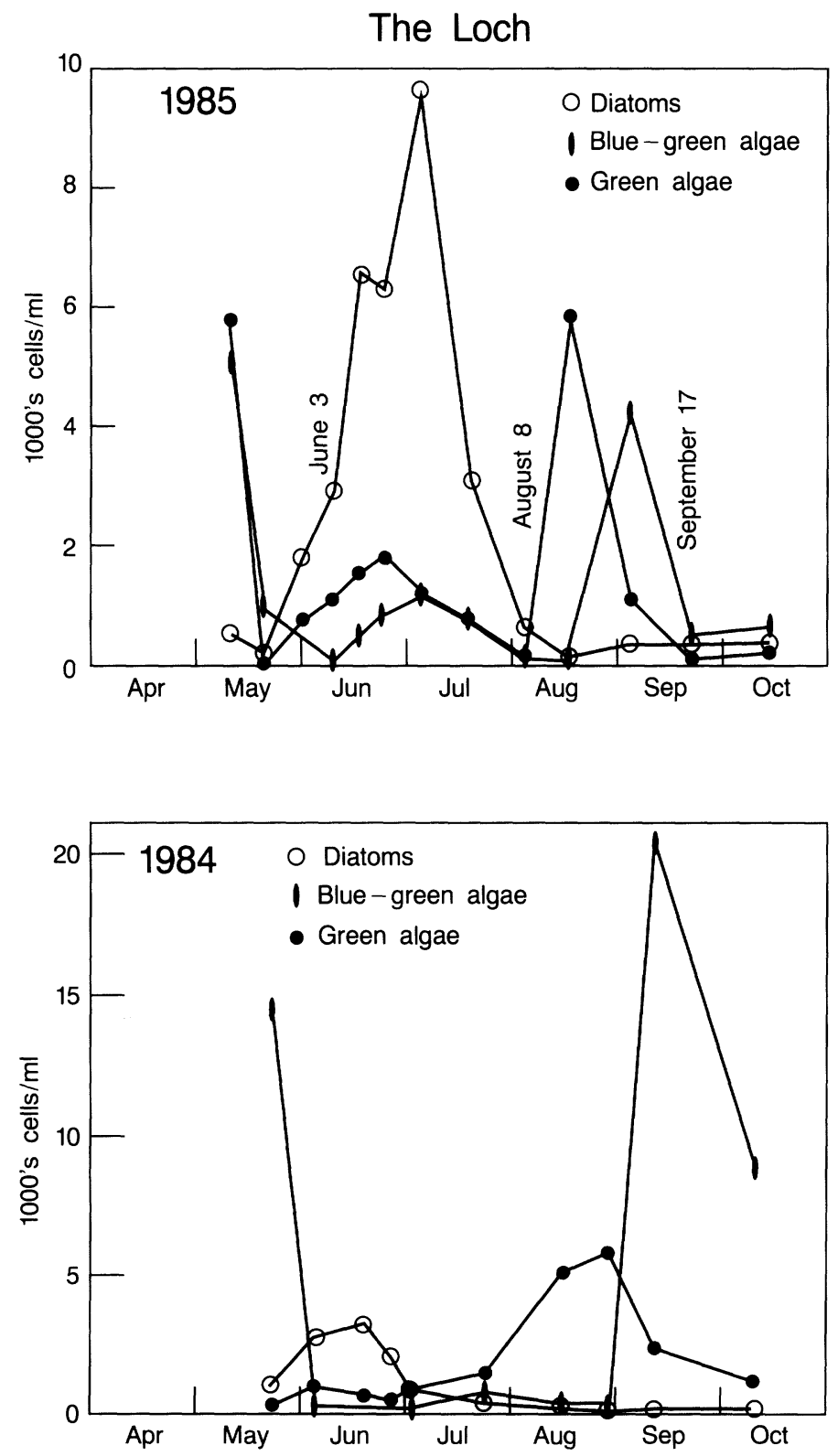

four other alpine lakes within $10 \mathrm{~km}$ of Loch Vale were sampled for phytoplankton to assess the occurrence of cyanophyte dominance (McKnight, unpublished data). In Bierstadt Lake, which had the greatest algal abundance $\left(1.0 \times 10^{5}\right.$ cells $\left./ \mathrm{ml}\right)$, several species of blue-green algae were dominant. For the other lakes, with cell densities from $2 \times 10^{3}$ and $9 \times 10^{3}$ cells $/ \mathrm{ml}$, the phytoplankton was dominated by chrysophytes and cryptophytes (Bear Lake and Nymph Lake) or chlorophytes (Sprague Lake).

\section{Zooplankton Abundance in The Loch}

The most abundant zooplankters in The Loch were rotifers Polyarthra sp. $\left(3 \times 10^{3}\right.$ to $5 \times 10^{3}$ organisms $\left./ \mathrm{m}^{3}\right)$ and Notholca sp. $\left(1.3 \times 10^{3}\right.$ organisms $\left./ \mathrm{m}^{3}\right)$. The peak
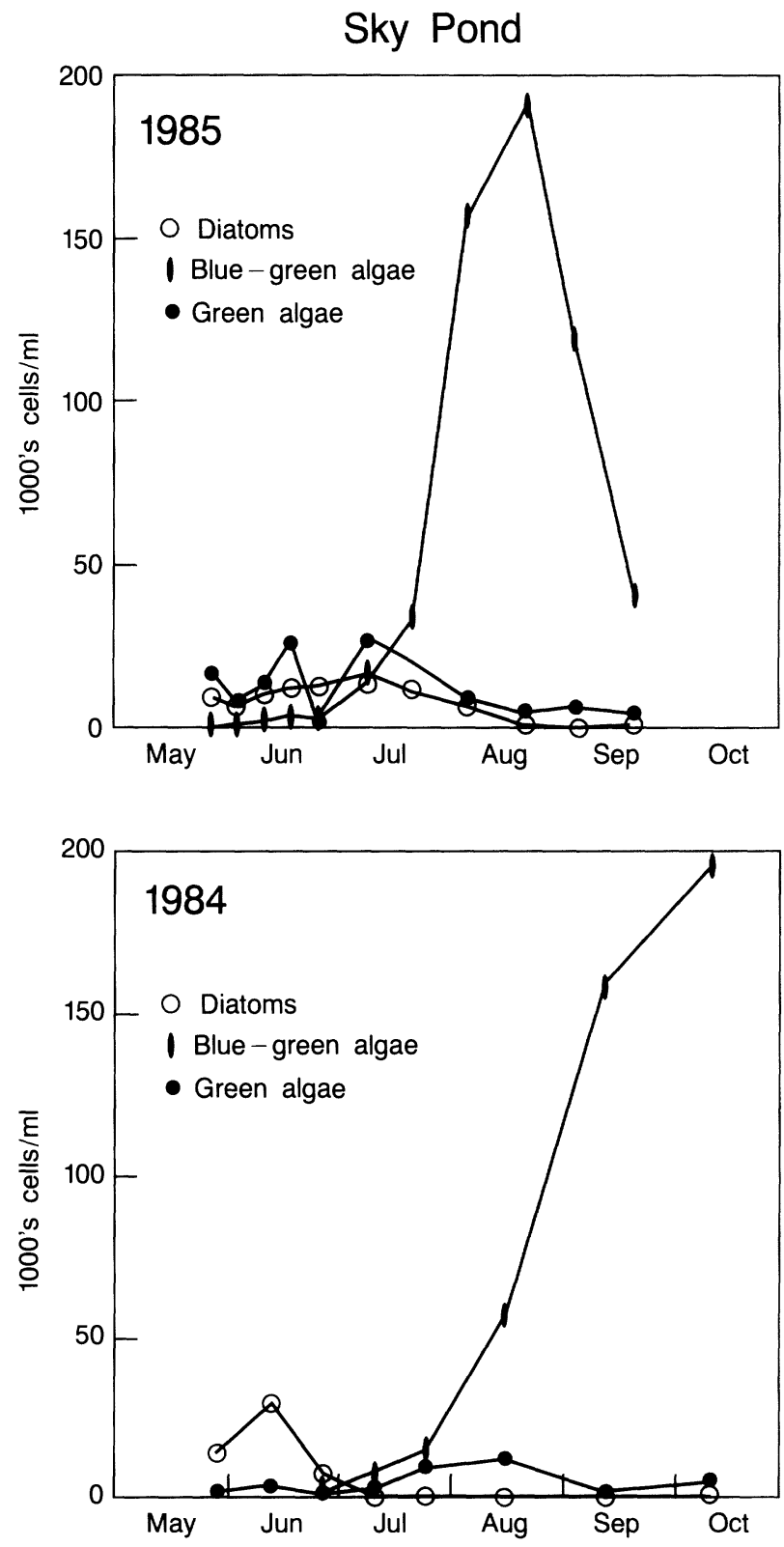

Figure 2. Abundance of major algal phyla in The Loch (A) and Sky Pond (B) in 1984 and 1985. 
abundance of rotifers occurred during and after the decrease in the flushing rate and was coincident with the minimum in the $A$. formosa population (McKnight et al., 1988). The anatomy of these rotifer species make them capable of consuming $A$. formosa by breaking the frustule and ingesting the cellular contents (Pennak, 1978; May, 1980). In a study of a Scottish lake, May (1980) reported that under favorable temperature regimes (less than $10^{\circ} \mathrm{C}$ ), the abundance of the rotifer Notholca squamula was related to the abundance of $A$. formosa. The decrease in flushing rate as snowmelt ended may have allowed for the development of rotifer populations, and zooplankton grazing may have caused the midsummer decrease in the phytoplankton populations (Crumpton and Wetzel, 1982).

The Loch Outlet

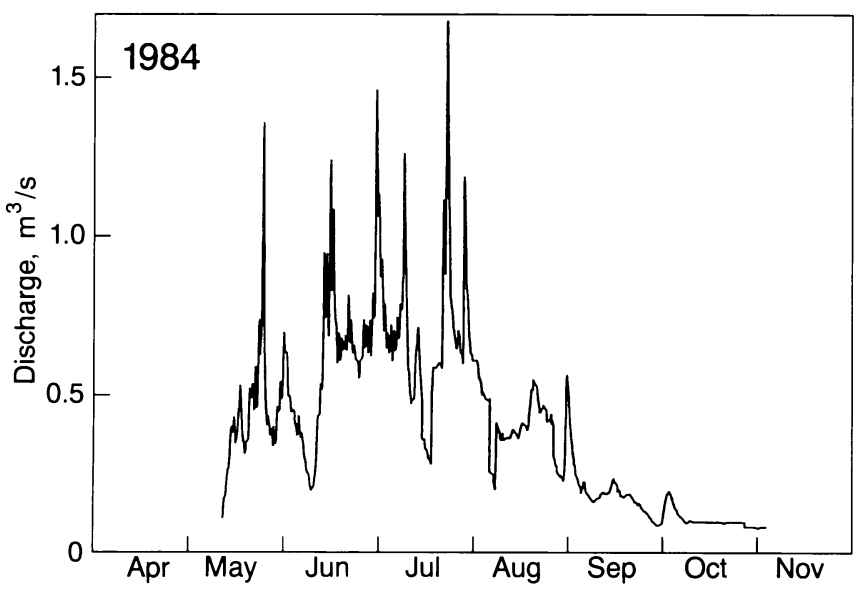

Primary Productivity in The Loch

The results of the primary productivity depth profiles for 3 June, 8 August, and 17 September 1985 are listed in Table 4. Primary productivity was greatest on 3 June 1985 , during the $A$. formosa bloom, which is consistent with the relatively rapid rates of increase of that population. Primary productivity was lowest on 8 August 1985, during the algal minimum. Because primary productivity was measured only during the latter period of the $O$. limnetica bloom, these rates may not be representative of the actively growing population. The photosynthetic rates measured during August and September 1985 are typical of rates reported for temperate lakes during the summer (Wetzel, 1983; Sakamoto et al., 1984). The 10 -fold faster photosynthetic rate during June 1985 indi-

FIGURE 3. Discharge measured at the Icy Brook outflow of The Loch during 1984 (A) and 1985 (B).

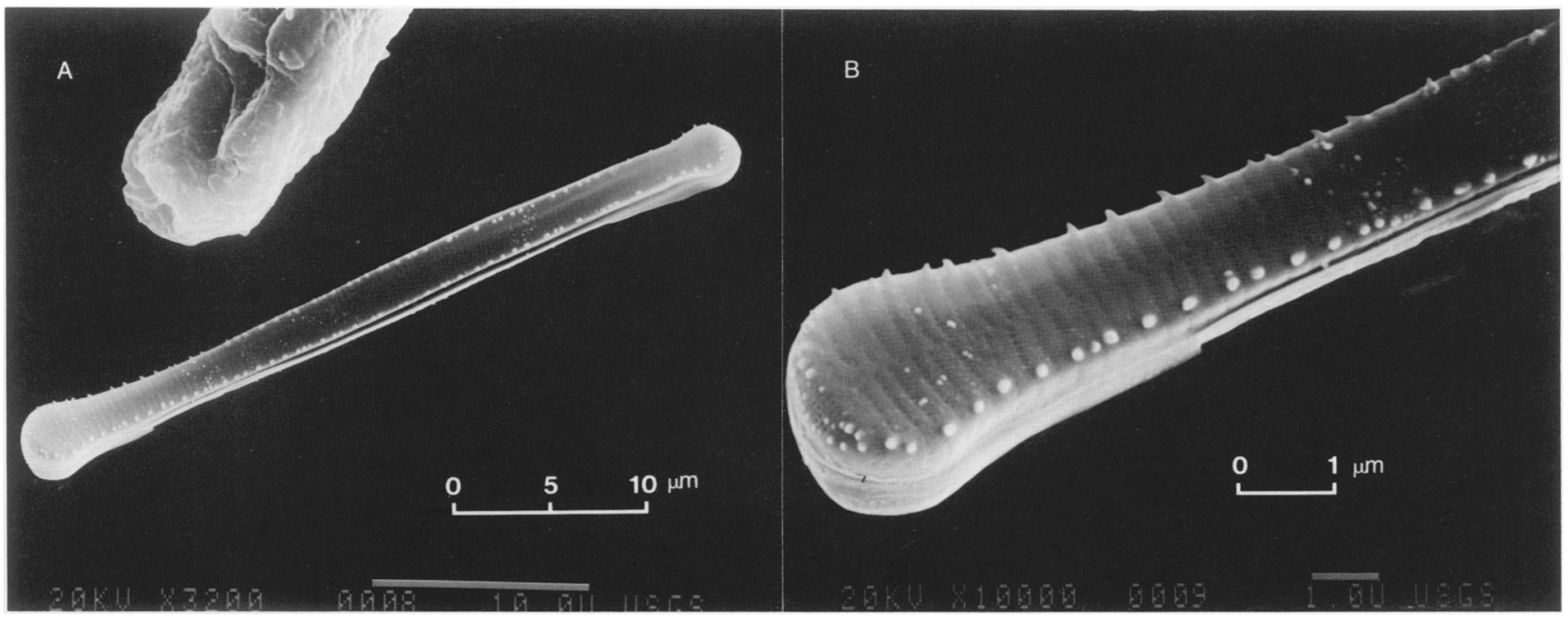

FIGURE 4. Scanning electron micrographs of Asterionella formosa from The Loch at 3200 (A) and 10,000 (B) times magnification. 
cates the importance of rapid real biological growth during the snowmelt period.

Photoinhibition is a possible effect of exposure to greater light intensities after ice break-up. The change in light regime with ice breakup depends upon the accumulation of snowpack on the lake ice, which in turn depends on wind and other climatic conditions. Strong winds are common in Loch Vale, and the lake ice is usually free of snow during the winter. The primary productivity depth profile indicates that a photoinhibition effect was confined to the upper meter of the water column immediately after ice breakup on 3 June. No evidence of photoinhibition was detectable on 8 August or 17 September 1985.

\section{Response to Nitrate AND Sulfate ENRICHMENT}

An increase in nitrate concentration (from $73 \mu \mathrm{M}$ to $85 \mu \mathrm{M}$ ) occurs during snowmelt in the lakes in Loch Vale (McKnight et al., 1988). After snowmelt, $\mathrm{NO}_{3}$ concentrations gradually decrease to $25 \mu \mathrm{M}$. The concentrations

TABLE 3

Abundance and estimated net growth of Asterionella formosa in The Loch during the snowmelt period of 1985

\begin{tabular}{|c|c|c|c|c|c|c|c|c|c|}
\hline \multirow[b]{2}{*}{ Date } & \multirow[b]{2}{*}{$\begin{array}{c}\text { Discharge } \\
\left(\mathrm{m} \mathrm{s}^{-3}\right)\end{array}$} & \multirow[b]{2}{*}{$\begin{array}{c}\text { Flushing } \\
\text { rate, } \mathrm{R} \\
\left(\mathrm{d}^{-1}\right)\end{array}$} & \multicolumn{6}{|c|}{ Abundance (cells per milliliter) } & \multirow[b]{2}{*}{$\begin{array}{c}\text { Effective rate } \\
\text { of increase } \\
\text { per day }\left(\mu^{f}\right)\end{array}$} \\
\hline & & & Inlet $\mathbf{A}_{\mathrm{I}}^{\mathrm{a}}$ & $\mathrm{B}^{\mathrm{b}}$ & $\mathbf{M}^{\mathrm{c}}$ & $S^{d}$ & Outlet & $\mathrm{A}_{\mathrm{L}}{ }^{\mathrm{e}}$ & \\
\hline 3 June & 0.40 & 0.56 & 966 & 1390 & 1362 & 1732 & 1420 & 1576 & 0.35 \\
\hline 12 June & 0.47 & 0.66 & 3238 & 5197 & 4885 & 2840 & 7043 & 4991 & 0.36 \\
\hline 19 June & 0.47 & 0.66 & 3238 & 5197 & 4885 & 2840 & 7043 & 4991 & 0.36 \\
\hline 10 July & 0.40 & 0.56 & 4288 & 9159 & 6844 & 9060 & 6930 & 7988 & 0.48 \\
\hline 23 July & 0.39 & 0.55 & 1988 & 3806 & 1420 & 2954 & 1889 & 2517 & 0.15 \\
\hline
\end{tabular}

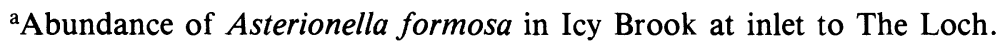

${ }^{b}$ Bottom depth.

cMid-depth.

dSurface.

${ }^{\mathrm{e}}$ Average abundance from the bottom depth, mid-depth, surface, and outlet.

${ }^{\mathrm{f}}$ Calculated using the equation: $\mu=\mathrm{R}\left(\mathrm{A}_{\mathrm{L}}-\mathrm{A}_{\mathrm{I}}\right) / \mathrm{A}_{\mathrm{I}}$.

TABLE 4

Photosynthetic rate $\left[\left(\mu \mathrm{g} \mathrm{C} \cdot \mathrm{L}^{-1}\right) \mathrm{h}^{-1}\right]$, chlorophyll a $\left(\mu \mathrm{g} \mathrm{L}^{-1}\right)$ and photosynthetically active radiation (PAR $\mu \mathrm{E} \cdot \mathrm{m}^{-2} \cdot \mathrm{s}^{-1}$ ) as a function of depth in The Loch during the open-water period of 1985

\begin{tabular}{|c|c|c|c|c|c|}
\hline \multirow[b]{2}{*}{ Parameter } & \multicolumn{5}{|c|}{ Depth (m) } \\
\hline & 0 & 1 & 2 & 3 & 4 \\
\hline \multicolumn{6}{|c|}{3 June } \\
\hline Photosynthetic rate & $\begin{array}{c}46 \\
(40-52)^{a}\end{array}$ & $\begin{array}{c}61 \\
(60.6-61.3)\end{array}$ & $\begin{array}{c}9 \\
(7.6-10.4)\end{array}$ & $\begin{array}{c}10 \\
(7.4-13.1)\end{array}$ & $\begin{array}{c}19 \\
(17-20)\end{array}$ \\
\hline Chlorophyll $a$ & 1.2 & - & 1.3 & - & 1.4 \\
\hline PAR $(1430 \mathrm{~h})$ & 750 & 250 & 170 & - & - \\
\hline \multicolumn{6}{|c|}{8 August } \\
\hline Photosynthetic rate & $\begin{array}{c}3.7 \\
(3.1-4.3)\end{array}$ & $\begin{array}{c}3.8 \\
(3.5-4.3)\end{array}$ & $\begin{array}{c}3.7 \\
(3.0-4.4)\end{array}$ & $\begin{array}{c}3.7 \\
(3.1-4.3)\end{array}$ & $\begin{array}{c}1.0 \\
(0.95-1.05)\end{array}$ \\
\hline Chlorophyll $a$ & 1.0 & - & 1.3 & - & 1.5 \\
\hline PAR (1045 h) & 1250 & 750 & 650 & 300 & 400 \\
\hline \multicolumn{6}{|c|}{17 September } \\
\hline Photosynthetic rate & $\begin{array}{c}8.0 \\
(7.3-8.3)\end{array}$ & $\begin{array}{c}7.4 \\
(6.9-7.9)\end{array}$ & - & - & - \\
\hline Chlorophyll $a$ & 1.4 & - & 1.5 & - & 1.0 \\
\hline PAR $(1140 \mathrm{~h})$ & 1900 & 950 & - & - & - \\
\hline
\end{tabular}

${ }^{a}$ Range of duplicates or triplicates shown in parentheses. 
of $\mathrm{PO}_{4}$, another important nutrient for phytoplankton, are very low $(\leq 0.1 \mu \mathrm{M})$ and do not change in a consistent seasonal pattern. Short-term enrichment experiments were conducted to evaluate the possible effect of this seasonal change in nitrate concentration.

The sensitivity of the phytoplankton to nitrate and sulfate enrichment was assessed by adding amendments in duplicate to lake water samples that then were spiked with a ${ }^{14} \mathrm{C}-\mathrm{HCO}_{3}$ tracer and incubated in the lake. Nitrate was added as a calcium salt and as an acid to distinguish between effects from decreases in $\mathrm{pH}$ and from increases in nitrate. Sulfuric acid amendments were used to see if an amendment with an acid which was not a major nutrient had an effect. The amendment experiments were conducted in 1985 at the beginning of the diatom bloom (3 June) and the latter period of the cyanophyte bloom (17 September) as indicated in Figure 2. In situ incubations were used to minimize stress associated with handling and transport from the lake site. The results of these experiments are listed in Table 5. With the exception of the low $\mathrm{pH}$ amendments, the responses to the various amendments were similar on the two occasions despite the major differences in the phytoplankton composition. Amendments with $\mathrm{Ca}\left(\mathrm{NO}_{3}\right)_{2}$ and $\mathrm{H}_{2} \mathrm{SO}_{4}$ generally had more of a stimulatory effect than $\mathrm{HNO}_{3}$ amendments.

On 3 June 1985, when an actively growing population of $A$. formosa dominated the phytoplankton, all the $\mathrm{Ca}\left(\mathrm{NO}_{3}\right)_{2}$ amendments stimulated the photosynthetic rate as measured by ${ }^{14} \mathrm{C}$-uptake. The greatest increase resulted from the 808- $\mu \mathrm{M}$ amendment. All four $\mathrm{HNO}_{3}$ amendments caused a similar slight increase, including the amendment that decreased the $\mathrm{pH}$ to 3.17 . The two $\mathrm{H}_{2} \mathrm{SO}_{4}$ amendments increased the measured photosynthetic rate to greater extents, with a threefold increase for the 808- $\mu \mathrm{M}$ amendment, which decreased to $\mathrm{pH}$ 3.27. The fact that sulfate amendments had a similar effect as $\mathrm{Ca}\left(\mathrm{NO}_{3}\right)_{2}$ amendments argues against a direct response to an increased nutrient $\left(\mathrm{NO}_{3}\right)$ concentration. The low or below detection limit, trace metal concentrations in the amendment solutions (resulting in sample concentrations less than or equal to 0.1 to $0.05 \mu \mathrm{M}$ ) limit the possibility of a trace metal stimulation. No other artefactual effect was identified. The stimulatory effect could be related to the dilute nature of the lakewater. In a study of phosphate uptake by $A$. formosa, Mackereth (1953) determined that uptake consistently was greater in lakewater than in distilled water. The stimulation of phytoplankton growth by several nutrients and trace metals also was detected by Goldman (1960) in a lake on the Alaska Peninsula. The positive response in The Loch to such varying additions, although not readily explained, is at least consistent with these results.

During the $O$. limnetica bloom, intermediate amendments of $\mathrm{Ca}\left(\mathrm{NO}_{3}\right)_{2}$ and $\mathrm{H}_{2} \mathrm{SO}_{4}$ also caused increases in ${ }^{14} \mathrm{C}$-uptake. The 8.1- and $16.2-\mu \mathrm{M}$ amendments of $\mathrm{Ca}\left(\mathrm{NO}_{3}\right)_{2}$ caused about a $50 \%$ increase in the photosynthetic rate. The 808- $\mu \mathrm{M}$ amendment had the same photosynthetic rate as that for the unamended controls.
TABLE 5

Effect of nitrate and sulfate enrichment on photosynthetic rate

\begin{tabular}{|c|c|c|c|}
\hline \multicolumn{2}{|c|}{ Amendment } & \multicolumn{2}{|c|}{$\begin{array}{l}\text { Photosynthetic rate } \\
\quad\left(\left[\mu \mathrm{g} \mathrm{C} \mathrm{L}^{-1}\right] \mathrm{h}^{-1}\right)\end{array}$} \\
\hline Solutes added & Concentrations $(\mu \mathrm{M})$ & 3 June & 17 September \\
\hline None & - & 9 & 3.7 \\
\hline $\mathrm{Ca}\left(\mathrm{NO}_{3}\right)_{2}$ & 3.2 & 27 & - \\
\hline $\mathrm{Ca}\left(\mathrm{NO}_{3}\right)_{2}$ & 8.1 & 13 & 5.4 \\
\hline $\mathrm{Ca}\left(\mathrm{NO}_{3}\right)_{2}$ & 16.2 & 32 & 5.4 \\
\hline $\mathrm{Ca}\left(\mathrm{NO}_{3}\right)_{2}$ & 808 & 46 & 3.5 \\
\hline $\mathrm{H}_{2} \mathrm{SO}_{4}$ & 8.1 & - & 5.9 \\
\hline $\mathrm{H}_{2} \mathrm{SO}_{4}$ & 16.2 & 53 & 6.0 \\
\hline $\mathrm{H}_{2} \mathrm{SO}_{4}$ & 808 & 34 & 0.24 \\
\hline $\mathrm{HNO}_{3}$ & 3.2 & 15 & - \\
\hline $\mathrm{HNO}_{3}$ & 8.1 & 14 & 3.5 \\
\hline $\mathrm{HNO}_{3}$ & 16.2 & 12 & 4.2 \\
\hline $\mathrm{HNO}_{3}$ & 808 & 12 & 1.8 \\
\hline
\end{tabular}

${ }^{\text {a On }} 3$ June 1985, samples were obtained from 2-m depths and were incubated at 2-m depths; on 17 September, the samples were obtained from 1-m depths and were incubated at $1-\mathrm{m}$ depths. Values are averages for duplicate incubations, range was $\pm 20 \%$ or less.

For $\mathrm{H}_{2} \mathrm{SO}_{4}$, the 8.1- and $16.2 \mu \mathrm{M}$ amendments caused a $67 \%$ increase in photosynthetic rate, but the $808-\mu \mathrm{M}$ amendment, which decreased the $\mathrm{pH}$ to 3.2 , decreased the ${ }^{14} \mathrm{C}$ uptake to less than $10 \%$ of the rate in unamended incubations. For $\mathrm{HNO}_{3}$, the 8.1- and 16.2- $\mu \mathrm{M}$ amendments did not cause a substantial change in photosynthetic rates of $O$. limnetica, and the $808-\mu \mathrm{M}$ amendment, which decreased the $\mathrm{pH}$ to 3.2 , caused a two-fold decrease in photosynthetic rate. In these experiments, the intermediate concentrations of $\mathrm{Ca}\left(\mathrm{NO}_{3}\right)$ and $\mathrm{HNO}_{3}$, where there were no changes in $\mathrm{pH}$, did not have the same stimulatory effect on growth, which again argues against a direct nutrient effect.

An interesting contrast between the two amendment experiments, was that the $A$. formosa population was not inhibited by the low $\mathrm{pH}$ values of the maximum $\mathrm{HNO}_{3}$ and $\mathrm{H}_{2} \mathrm{SO}_{4}$ enrichments and the $O$. limnetica population was significantly inhibited. The inhibitory effect for $O$. limnetica is consistent with the general observation that cyanophytes are not present in acidic environments $(\mathrm{pH}$ $<4.0$ ) (Brock, 1973). Although $A$. formosa is classified as an alkaliphilic diatom species (pH 6.4 to 7.8) based on its distribution in Adirondack lakes (Charles, 1985), it is also moderately abundant in lakes in northern Quebec that range in $\mathrm{pH}$ from 4.5 to 6.4 (Hudon et al., 1986). One possible explanation of the short-term low pH tolerance of $A$. formosa in Loch Vale is that the $A$. formosa in Loch Vale may be a physiological subspecies distinct from the classical form found in temperate-zone lakes. 


\section{DISCUSSION}

In temperate lakes, two main influences on phytoplankton succession are losses by zooplankton grazing and sedimentation (Crumpton and Wetzel, 1982) and interspecific resource-based competition (Carney et al., 1988). The alpine-subalpine lake system studied here may be a system where hydrologic processes are as important as these processes in controlling the seasonal succession of phytoplankton.

\section{Hydrologic Control - Analogy to Continuous Cultures in SeQuence}

Comparing the hydrologic data (Figure 3) to taxa abundance (Figure 2) emphasizes the importance of hydrology on bloom phenomena-A. formosa bloomed during high-flow conditions caused by snowmelt, and $O$. limnetica bloomed during low-flow conditions. Phytoplankton dynamics of the Loch Vale lakes may be compared with the dynamics of three continuous algal cultures connected in sequence. In this analogy, Icy Brook corresponds to the "tubing," transporting the outflow from Sky Pond and any shallow groundwater inflows to Glass Lake, the next continuous culture in the sequence. During the snowmelt period, the chemostat pumps can be thought of as being set on full speed, and only algae that are growing at a net rate that exceeds the flushing rate will increase in abundance. Under these conditions, more slowly growing species will be flushed out of the system. In addition to populations of more slowly growing algal species, populations of zooplankton may be limited by rapid flushing rates.

As snowmelt ends, the flushing rates of the study lakes decrease which, in the comparison with three continuous cultures in sequence, corresponds to a decrease in the flow rate of the pump. During low flow, more slowly growing algal species will remain in the system longer and, as a result of differences in grazing pressure or nutrient utilization, may become the dominant species and replace species with rapid maximum growth rates. In this context, it is interesting to note that in 1985 the $O$. limnetica bloom developed earlier than in 1984. This difference may have been related to the earlier decrease in the flushing rate in 1985 as indicated by discharge (Figure 3).

\section{Grazing and Nutrient Competition}

Decreases in flushing rate after snowmelt would allow for effects of zooplankton grazing and nutrient competition to become more important controls on the phytoplankton. In midsummer in 1985 , the decrease in discharge and $A$. formosa populations were coincident with an increase in herbivorous rotifers. This is circumstantial evidence for a zooplankton grazing effect.

On the basis of competition for nutrients, a decrease in flushing rate would also be expected to result in a change in algal dominance. In a unialgal continuous culture system with a constant inflow nutrient concentration, a decreased flow rate would result in greater cell densities and lesser nutrient concentrations in the cultures. In a lake system, decreasing nutrient concentrations would favor species that are capable of utilizing minimal nutrient concentrations. The importance of such a nutrient competition effect cannot be determined from the nitrate and sulfate enrichment experiments. At intermediate concentrations (up to $16 \mu \mathrm{M}$ ) both anions had stimulatory effects during the two periods of $A$. formosa and $O$. limnetica dominance. These results leave open the possibility that the seasonal changes in nitrate concentrations have an influence on phytoplankton dynamics; however, because both anions had a stimulatory effect they cannot be interpreted as demonstrating that nitrate is a limiting nutrient in this lake system. Gotham and Rhee (1981) studied the $\mathrm{NO}_{3}$ requirements of $A$. formosa and determined the average half saturation coefficient $\left(K_{s}\right)$ to be $1.3 \pm 0.3 \mu \mathrm{M}$. Halterman and Toetz (1984) reported that four species of freshwater diatoms had $K_{s}$ values ranging from 2.6 to $7 \mu \mathrm{M}$. These $K_{s}$ values are less than $\mathrm{NO}_{3}$ concentrations in The Loch $(85-25 \mu \mathrm{M})$. The two other major nutrients that may be important are phosphate and silica. $A$. formosa can efficiently utilize minimal phosphate concentrations (Mackereth, 1953). The requirements of $A$. formosa for $\mathrm{SiO}_{2}$ and $\mathrm{PO}_{4}$ have been further studied in laboratory experiments using unialgal cultures (Titman, 1976; Tilman 1977).

\section{CONCLUSIONS}

Two main events in the phytoplankton succession in lakes in Loch Vale, Rocky Mountain National Park, were a bloom of the diatom Asterionella formosa during snowmelt in the spring and a bloom of the cyanophyte Oscillatoria limnetica during low flow in the fall. The hydrologic regime, which is dominated by snowmelt, appears to be as important a control on the seasonal phytoplankton dynamics as grazing and interspecific resourcebased competition. The coincident occurrence of decreases in the $A$. formosa population and discharge from the lake, and increases in zooplankton populations sug- gests that zooplankton grazing limits the diatom bloom after snowmelt. Nitrate and sulfate enrichment experiments showed stimulatory effects at concentrations in the range 8 to $16 \mu \mathrm{M}$.

\section{ACKNOWLEDGMENTS}

This study was conducted by the U.S. Geological Survey as part of the National Acid Precipitation Assessment Program with the collaboration and support of the National Park Service, Water Resources Laboratory, Rocky Mountain National Park, and the Colorado State University Natural Resources 
Ecology Laboratory. We acknowledge the onsite assistance provided by Steven Zary, Brian Olver, David Beeson, Andrea Alpine, and Richard Marzolf. Identification and enumeration of algal species was performed by Richard Duford, Steven Canton, and James Chadwick of Chadwick and Associates, Little- ton, Colorado. Trace metal analysis of amendment solutions was done by Richard Harnish and Chris Miller. We appreciate discussions with Richard Marzolf, James LaBaugh, Robert Averett, and Carl Bowser, and review comments from Andrea Alpine, Frank Triska, and Heath Carney.

\section{REFERENCES CITED}

Baron, J. A., Norton, S. A., Beeson, D. R., and Merrmann, R., 1986: Sediment diatoms and metal stratigraphy from Rocky Mountain lakes, with special reference to atmospheric deposition. Canadian Journal of Fisheries and Aquatic Science, 43: 1350-1362.

Baron, J. and Bricker, O. P., 1987: Hydrologic and chemical flux in Loch Vale Watershed, Rocky Mountain National Park. In Averett, R. C. and McKnight, D. M. (eds.), Chemical Quality of Water and the Hydrologic Cycle. Chelsea, MI: Lewis Publishers, Inc., pp. 141-156.

Brinley, F. J., 1950: Plankton population of certain lakes and streams in the Rocky Mountain National Park, Colorado. Ohio Journal of Science, 50: 243-250.

Brock, T. D., 1973: Evolutionary and ecological aspects of the cyanophytes in the biology of blue-green algae. In Carr, $\mathrm{N}$. G. and Whitton, B. A. (eds.), The Biology of Blue-Green Algae. Botanical Monographs 9. Berkeley: University of California Press, 487-501.

Canter, H. M. and Jaworski, G. H. M., 1978: The isolation, maintenance and host range studies of a chytrid Rhizophydium planktonicum Canter emend., parasite on Asterionella formosa Hassall. Annals of Botany, 42: 967-979.

Carney, H. J., Richardson, P. J., Goldman, C. R., and Richards, R. C., 1988: Seasonal phytoplankton demographic processes and experiments on interspecific competition. Ecology, 69: 664-678.

$\rightarrow$ Charles, D.F., 1985: Relationships between surface sediment diatom assemblages and lakewater characteristics in Adirondack lakes. Ecology, 66: 994-1011.

Charles, D. F. and Norton, S. A., 1986: Paleolimnological evidence for trends in atmospheric deposition of acids and metals. In Gibson, J. H. (ed.), Acid Deposition: Long-Term Trends. Washington, D.C.: National Academy Press, 335-434.

Crumpton, W. G. and Wetzel, R. G., 1982: Effects of differential growth and mortality in the seasonal succession of phytoplankton populations in Lawrence Lake, Michigan. Ecology, 63: 729-739.

Goldman, C. R., 1960: Primary productivity and limiting factors in three lakes of the Alaska Peninsula. Ecological Monographs, 30: 207-230.

Goldman, C. R. and Horne, A. J., 1983: Limnology. New York: McGraw-Hill. 464 pp.

Gotham, I. J. and Rhee, G., 1981: Comparative kinetic studies of nitrate-limited growth and nitrate uptake in phytoplankton in continuous culture. Journal of Phycology, 17: 309-314.

Halterman, S. G. and Toetz, D. W., 1984: Kinetics of nitrate uptake by freshwater algae. Hydrobiologia, 114: 209-214.

Hudon, C., Duthie, H. C., Smith, S. M., and Ditner, S. A., 1986: Relationships between lakewater $\mathrm{pH}$ and sedimentary diatoms in the Matamek Watershed, northeastern Quebec, Canada. Hydrobiologia, 140: 49-65.

Keefer, V. M. and Pennak, R. W., 1977: Plankton and seston of a Colorado (U.S.A.) alpine lake-The winter anomaly and the inlet-outlet budget. Internationale Revue der gesamten Hydrobiologie, 62: 255-278.

Koob, D. D., 1966: Parasitism of Asterionella formosa Hass. by a chytrid in two lakes of the Rawah Wilderness Area of Colorado. Journal of Phycology, 2: 41-45.

Lewis, W. M., Jr. and Grant, M. C., 1979: Relationships between flushing and yield of dissolved substances from a mountain watershed. Soil Science, 128: 353-363.

Lund, J. W. G., Kipling, L., and LeCren, E. D., 1958: The inverted microscope method of estimating algal numbers and the statistical basis of estimations by counting. Hydrobiologia, 11: $143-170$.

Mackereth, F. J., 1953: Phosphorous utilization by Asterionella formosa Hass. Journal of Experimental Botany, 4: 296-313.

May, L., 1980: On the ecology of Notholca squamula Muller in Loch Leven, Kinross, Scotland. Hydrobiologia, 73: 177-180.

McKnight, D. M., Brenner, M., Smith, R. L., and Baron, J. A., 1986: Seasonal changes in phytoplankton populations and related chemical and physical characteristics in lakes in Loch Vale, Rocky Mountain National Park, Colorado. U.S. Geological Survey Water-Resources Investigations Report, 86-4101. $64 \mathrm{pp}$.

McKnight, D. M., Miller, C., Smith, R. L., Baron, J. A., and Spaulding, S., 1988: Phytoplankton populations in lakes in Loch Vale, Rocky Mountain National Park, ColoradoSensitivity to acidic conditions and nitrate enrichment. U.S. Geological Survey Water-Resources Investigations Report, 88-4115. $00 \mathrm{pp}$.

Olive, J. R., 1953: Some aspects of plankton associations in the high mountain lakes of Colorado. Verhandlungen. Internationaler Vereinigung für Theoretische und Angewandte Limnologie, 12: 425-435.

$\rightarrow$ Pennak, R. W., 1949: An unusual algal nuisance in a Colorado mountain lake. Ecology, 30: 245-247.

1963: Rocky Mountain states. In Frey, D. G. (ed.), Limnology in North America. Madison: University of Wisconsin Press, 349-370.

, 1978: Fresh-water Invertebrates of the United States. 2nd ed. New York: John Wiley. 803 pp.

Renberg, I. and Hellberg, T., 1982: The pH history of lakes in southwestern Sweden, as calculated from the subfossil diatom flora of the sediments. Ambio, 11: 30-33.

Reynolds, C. S., 1984: Ecology of Freshwater Plankton. Cambridge: Cambridge University Press. 345 pp.

Rott, E., 1988: Some aspects of the seasonal distribution of flagellates in mountain lakes. Hydrobiologia, 161: 159-170.

Sakamoto, M., Tilzer, M. M., Gachter, R. H., Collos, Y., Tschumi, P., Berner, P., Zbaren, D., Zbaren, J., Dokulil, M., Bossard, P., Uehlinger, U. and Nusch, E. A., 1984: Joint field experiments for comparisons of measuring methods of photosynthetic production. Journal of Plankton Research, 6: $365-383$. 
Shero, B., 1987: Personal communication. Medaville College, Medaville, New York.

Skougstad, M. W., Fishman, M. J., Friedman, L. C., Erdmann, D. E., and Duncan, S. S., (eds.), 1979: Methods for determination of inorganic substances in water and fluvial sediments. U.S. Geological Survey Techniques of WaterResources Investigations, bk. 5, chap. A1. 626 pp.

Sommer, U., 1983: Nutrient competition between phytoplankton species in multispecies chemostat experiments. Archiv für Hydrobiologia, 96: 399-416.

Strickland, J. D. H. and Parsons, T. R., 1972 A practical handbook of seawater analysis. 2nd ed. Fisheries Research Board of Canada Bulletin, 167, 310 pp.

$\rightarrow$ Tilman, D., 1977: Resource competition between planktonic algae-An experimental and theoretical approach. Ecology, 58: $338-348$.
Tilman, D. and Kilham, S. S., 1976: Phosphate and silicate growth and uptake kinetics of the diatoms Asterionella formosa and Cyclotella meneghiniana in batch and semicontinuous culture. Journal of Phycology, 12: 375-483.

Titman, D., 1976: Ecological competition between algae - experimental confirmation of resource-based competition theory. Science, 192: 463-465.

Vollenweider, R. A., 1969 A Manual on Methods for Measuring Primary Productivity in Aquatic Environments. IBP Handbook 12. Oxford: Blackwell Scientific Publications. 213 pp.

Wetzel, R. G., 1983: Limnology. New York: Saunders Publishing. 767 pp.

Ms submitted July 1989 